\title{
JUSTICIA Y ORDEN SOCIAL: DELINCUENCIA Y REPRESIÓN DEL DELITO EN LOGROÑO EN EL SIGLO XVIII
}

\author{
José Luis Gómez Urdáñez \\ Juan Ibáñez Castro \\ Isabel Ilzarbe López \\ Diego Moreno Galilea \\ Universidad de La Rioja
}

Suma virtud es obrar bien por amor del premio, pero también es virtud no obrar mal por temor de la pena. ${ }^{1}$

RESUMEN: A través de los expedientes originados en el marco de la justicia impartida por el corregidor de Logroño en el siglo XVIII intentamos comprender el amplio campo de la delincuencia y el papel moralizador del juez. Los procesos judiciales, desde la denuncia a la sentencia, pasando generalmente por la estancia preventiva en la cárcel, contienen información sobre el orden social, que tras haber sido quebrantado, ha de ser de nuevo, institucionalmente, reparado, en beneficio de Dios y el rey.

Palabras clave: Historia del derecho, siglo XVIII, proceso judicial, delitos, orden social, marginación.

\section{JUSTICE AND SOCIAL ORDER: CRIME AND PUNISHMENT IN LOGROÑO IN THE EIGHTEENTH CENTURY}

ABSTRACT: Based on the records originated in the framework of the justice given by the corregidor of Logroño in the 17th century, we attempt to understand the broad field of the delinquency and the moralising role of the judge. The

1. GONZÁLEZ, G., El Guitón Onofre, Edición de Fernando Cabo Aseguinolaza, Logroño, Gobierno de La Rioja, 1995, p. 225. 
judicial processes, from the sentence to the preventive stay in prison, contain information about the social order, which after being violated, has to be again institutionally repaired in benefit of god and the king.

Keywords: History of law, XVIII century, judicial process, crimes, social order, marginalization.

Los estudios de casos para comprobar empíricamente el funcionamiento de la justicia en la Edad Moderna en un ámbito generalmente urbano han tenido en los últimos años un notable desarrollo², pero como decía el maestro Tomás y Valiente, "el historiador no debe limitarse a exponer y comentar unos datos, sino ocuparse de ordenarlos y buscarles su más hondo sentido" ${ }^{\prime 3}$. Por eso, nuestro estudio pretende no sólo describir a través de los distintos casos estudiados una realidad histórica determinada, sino también "esclarecer los supuestos, los principios y los tópicos vivos en la ciencia y en la legislación de cada época", tal y como proponía el maestro, ${ }^{4}$ puesto que estos principios y tópicos tienen una correspondencia con la situación política, la mentalidad de la época y la sociabilidad del grupo humano al que determinan. ${ }^{5}$ Michel Foucault, en su clásico Vigilar y castigar, ya apreció que "el arte de castigar" exigía toda "una tecnología de la representación" y así, afirmaba que "la empresa no puede lograrse más que si se inscribe en una mecánica natural". Esta "representación" que la sociedad del siglo XVIII había interiorizado perfectamente se basaba, según Foucault, en varios principios, entre ellos, "ser lo menos arbitrarios posibles" -en cuanto a la aplicación de la ley-, "disminuir el deseo que hace atractivo el delito, aumentar el interés que convierte la pena en algo temible"; asegurar la utilidad de la pena, "intereses y duración" y, por fin, en cuanto al siglo reformador, es decir el XVIII y su impacto en las reformas, lideradas por Cesare Beccaria", "invertir en la socie-

2. Sin ánimo de ser exhaustivos, véase ORTEGA LÓPEZ, M., "Violencia familiar en el pueblo de Madrid durante el siglo XVIII", Cuadernos de Historia Moderna, 31 (2006), pp. 7-37; NIEVES GÁLVEZ, I., "La justicia y las conductas delictivas en Niebla y su tierra (1700-1750), Huelva en su historia-Segunda época, vol. 8, 2001, pp. 187-201; NAVARRO DOMÍNGUEZ, J. M., "Delincuencia en Carmona a fines del siglo XVIII a través de las fianzas de cárcel", Ascil. Anuario de Estudios Locales, año 5, 4 (2010), pp. 12-15; IGLESIAS ESTEPA, R., "El recurso a la justicia como vía de resolución de la conflictividad criminal gallega a fines del Antiguo Régimen. El ejemplo de Santiago de Compostela (1700-1834), Studia Historica, 26 (2004), pp. 349-374.

3. TOMÁS Y VALIENTE, F., El Derecho Penal de la monarquía absoluta (siglos XVI, XVII y XVIII), Madrid, 1992, p. 15.

4. TOMÁS Y VALIENTE, El Derecho Penal..., p. 15.

5. Una de las mejores obras para comprender la relación entre el orden social y la represión es la de SOUBEYROUX, J., "El encuentro del pobre y la sociedad: asistencia y represión en el Madrid del siglo XVIII", Estudios de historia social, 20-21 (1982), pp. 7-225.

6. Señalar la importancia de Beccaria puede parecer una obviedad, pero sigue siendo interesante leer su obra. Véase TOMÁS Y VALIENTE, Francisco, introducción en BONESANA, Cesare, marqués de Beccaria, De los delitos y de las penas, Madrid, $4^{a}$ reimpresión, Madrid, 
dad el tradicional discurso del delito", o lo que es lo mismo, inventar un nuevo discurso contra "esas alabanzas que hacen del criminal un héroe" y que en España estaban perfectamente representadas en la vida de los pícaros. ${ }^{7}$

Así pues, no tratamos sólo de aportar, caso tras caso, aquéllos que nos permitan conocer la "mala vida", como ha sido usual en buena parte de la historiografía tradicional, ${ }^{8}$ sino que pretendemos que estos casos contribuyan a proporcionar una visión holística de la sociedad y la época elegidas, en tanto en cuanto se constituye en marco de "representación" en el que la justicia es el orden máximo y su fuente, el rey, la única legitimación, pues él mismo está sostenido por Dios. La justicia es, pues, una representación de la didáctica de la vida social.

\section{Mandar es juzgar. El corregidor de Logroño}

En 1750, Logroño tenía unos 6.600 habitantes, según el vecindario del Catastro del Marqués de la Ensenada. ${ }^{9}$ Era una ciudad particular en cuanto al rango que ocupaba en Castilla, determinado por la figura del corregidor y sus competencias. Por ser Logroño frontera con las Provincias Exentas (Señoríos Vascongados) y con Navarra, es decir, una aduana importante del Cordón del Ebro, y por depender de la estructura defensiva y fiscal provocada por la particularidad del reino de Navarra, incorporado a la Corona de Castilla, pero con fiscalidad y leyes propias, el corregidor detentaba amplios poderes judiciales y militares. ${ }^{10} \mathrm{El}$ capitán general y virrey de Navarra delegaba en el corregidor de Logroño las funciones militares relativas al contrabando y la fiscalidad castellana, así como la gobernación del castillo, fortaleza sobre el puente de piedra al cargo de un alcaide, y el mando de las compañías de infantería y artillería situadas en la ciudad desde el siglo XVI. ${ }^{11}$ En cuanto a la competencia de juzgar pleitos civiles y criminales,

1982. Es igualmente importante consultar la obrita de uno de los traductores de Beccaria en España, véase LARRIZABAL, Manuel de, Discurso sobre las penas (1782), Cádiz, 2001, edición de Andrés Moreno Mengíbar.

7. FOUCAULT, M., Vigilar y castigar, Siglo XXI Editores, Madrid, 1975, p. 116.

8. Uno de los mejores ejemplos, DELEITO Y PIÑUELA, J., La mala vida en la España de Felipe IV, Madrid, 1987 (1ª ed. 1948, con prólogo de Gregorio Marañón).

9. ALONSO CASTROVIEJO, J. J., Logroño 1751. Según las respuestas generales del Catastro de Ensenada, Madrid, 1990.

10. MELÓN JIMÉNEZ, M. Á., Los tentáculos de la hidra. Contrabando y militarización del orden público en España (1784-1800), Madrid, Sílex, 2009.

11. En la ciudad de Logroño (...) Don Fernando García de la Plata Corregidor en propiedad por Su Majestad de ella su jurisdicción y partido y de sus agregados; Calahorra, Alfaro y Laguardia, capitán de guerra y capitán principal con las fronteras de Navarra; juez subdelegado de todas rentas, en AHPLR, Judicial, Leg. 2, Exp. 10. A sus órdenes un comandante general del cordón del Ebro. Véase AZCONA GUERRA, A. M., Comercio y Comerciantes en la Navarra del siglo XVIII, Estella, Gobierno de Navarra, 1996. Castillo de Bovadilla repara en las especiales circunstancias del corregimiento, por la frontera y la dependencia del corregidor del virrey de Navarra. Política para corregidores..., edic. fasc. Madrid, 1978, t. II, p. 377. 
el corregidor podía delegar, y lo hizo frecuentemente, en el alcalde preeminente, que es como se denominaba aquí a uno de los dos alcaldes, generalmente regidores perpetuos y pertenecientes a la oligarquía económica de la ciudad, bien por su estado noble, bien por su riqueza generalmente proveniente del comercio y del negocio del vino. ${ }^{12}$ También delegaba, sobre todo en materia de fiscalidad, rentas de la Corona y contrabando, en los alcaldes mayores de pueblos como Calahorra o Alfaro, donde era igualmente frecuente el tráfico ilícito pasando el Ebro y burlando las aduanas castellanas y las tablas navarras.

La Novísima Recopilación recogía estas particularidades que hacían del corregidor de Logroño un personaje más importante que el de una ciudad castellana cualquiera del interior. Obviamente, algunos casos estudiados en la documentación demuestran esta amplitud de competencias que viene determinada por la aduana y la frontera. Es muy destacable el tráfico de todo tipo de mercancías que entran por la aduana de Logroño y que da lugar tanto a un comercio enriquecedor lícito como un activo contrabando cuyo destino final, como ha demostrado Ana $M^{a}$ Azcona Guerra, es Francia y, sobre todo, la ciudad de Bayona. "Los comerciantes de Bayona, por un lado, y sus comisionistas vascofranceses y corresponsales navarros de Pamplona y de las principales localidades del Alto Ebro y La Rioja, por otro, conformaban un cordón umbilical que conectaba el puerto de Bayona con los centros de consumo y producción - de lana, vino y harinas- de Navarra, La Rioja y el nordeste castellano".13 En efecto, hemos encontrado numerosos casos que prueban la actividad juzgatoria del corregidor de Logroño en asuntos de contrabando, así como documentación que da cuenta del intenso tráfico y de la importancia de algunos productos que pasan de Francia al interior de Castilla, beneficiando a los comerciantes logroñeses y de otras localidades riojanas.

En lo demás, prácticamente la ciudad de Logroño tiene un comportamiento similar al resto de las ciudades castellanas, aunque es de destacar que tres siglos después de la expulsión de los judíos y, por tanto, de la irrupción de los primeros conversos en la vida social y política de la ciudad, todavía se sigan produciendo insultos recordando la limpieza de sangre o los sambenitos colgados en los muros de la iglesia de la Redonda. ${ }^{14}$ Ciertamente, Logroño mantuvo frecuentes episodios de venganzas entre conversos y cristianos viejos durante el siglo XVI y principio del XVII, por lo que no es sorprendente que el problema social de los conversos permaneciera en la memoria colectiva. ${ }^{15}$

12. ALONSO CASTROVIEJO, J. J., Problemática agraria, solución burguesa, Logroño, 1991.

13. AZCONA GUERRA, A. M., Comercio y Comerciantes en la Navarra del siglo XVIII, Estella, Gobierno de Navarra, 1996, pp. $51-52$.

14. Véanse algunos casos citados más adelante.

15. Historia de la ciudad de Logroño, Logroño, 1995, tomo 3. Uno de los hechos más resonantes de las luchas políticas en Logroño fue el asesinato de Jerónimo Ponce de León por un hidalgo, Pedro de Yanguas, en 1612, por haberse atrevido el converso Ponce de León a incluir a Pedro de Yanguas en el estado de los labradores y no en el de los hidalgos, véase BUSTOS 
Nuestro estudio, en fin, es posible gracias a la amplitud de las fuentes conservadas en su mayoría en la sección Judicial del Archivo Histórico Provincial de La Rioja. La sección Judicial está formada por expedientes de procesos juzgados por el corregidor, o el alcalde mayor en su representación. De todos ellos, hemos elegido un total cercano a los cien, la mayoría pleitos sobre las típicas reyertas originadas, bien por la apretada convivencia, sobre todo entre las clases populares, en pequeñas casas que comparten varias familias y que, por tanto, se ven expuestas a roces constantes, bien por enfrentamientos entre vecinos, en el campo o en el taller artesano. Así, hay varios casos de riñas entre mujeres o familiares que terminan en insultos, o agresiones menores y que se sustancian frecuentemente con la intervención paternalista del corregidor solicitando que las partes se avengan y se perdonen. En el escenario de la "representación" esta actitud paternalista tiene suma importancia pues remite directamente a la fuente del poder del que juzga y que no es otro que el rey, a quien el pueblo atribuye las virtudes de la clemencia del buen padre comprensivo. ${ }^{16}$

Otros casos frecuentes son los hurtos, a veces de pequeña monta, pero en algunos casos castigados con dureza, sobre todo cuando el reo puede ser por cualquier motivo incluido en el ambiguo y odioso mundo de los vagos; ${ }^{17}$ en ocasiones, la pena es de destino a los arsenales, donde los delincuentes se encontrarán con la justicia militar. ${ }^{18}$ Sin embargo, es de gran interés hacer notar ya desde ahora que también en estos casos la justicia tiene un fuerte componente de paternalismo y de ejemplificación del bien obrar, que se aplica también en estos casos siempre que se devuelva lo robado o que la condición del reo sea de suma pobreza.

La existencia de un fuero militar y de un fuero eclesiástico permitía al corregidor que después de instruir el proceso en el caso de aforados lo trasladara a las autoridades competentes. Hemos encontrado algún caso relativo al fuero militar, sobre todo cuando los reos son soldados de guarnición en la ciudad que provocan algún altercado; no hemos encontrado procesos relativos al fuero eclesiástico, bien porque los tribunales eclesiásticos actúan desde el comienzo, bien porque entra en funcionamiento la jurisdicción inquisitorial. Varios casos relativos a este último aspecto fueron ya expuestos en La Historia de la Ciudad de Logroño, y se refieren a delitos muy frecuentes como los de solicitación cometidos por los confesores, que en ningún caso se vieron por la justicia ordinaria. ${ }^{19}$

TORRE, S., El trabajo y los trabajadores en Logroño entre la peste y la gran crisis castellana (1599-1630), Tesis doctoral, Universidad de La Rioja, 2013, pág. 268.

16. LORENZO CADARSO, P. L., Los conflictos populares en Castilla, Madrid, 1997.

17. PÉREZ ESTÉVEZ, M. R., El problema de los vagos en la España del siglo XVIII, Madrid, Confederación Española de Cajas de Ahorros, 1976. Como dice la autora, a menudo las autoridad locales preferían enviar encadenado a la leva a cualquier forastero sospechoso que actuar contra los vecinos, lo que estos sabían reconocer.

18. Por ejemplo, AHPLR, judicial caja 76/15, año 1771.

19. Historia de la ciudad..., vol. 3, pp. 321-352. 
En definitiva, nuestro trabajo parte de la comprensión de la estructura social y política a través de la actuación de la justicia, fundamento del orden y el respeto debido a las instituciones, pues la actuación de la justicia en el Antiguo Régimen es la manera más visible de que todos comprendan la imagen que se suele proponer, que es la del miembro enfermo: si la sociedad ha enfermado por un miembro determinado, puede sanar actuando sobre ese miembro, bien por el castigo, bien por el arrepentimiento, siempre en nombre de una instancia superior cuya autoridad nunca fue puesta en duda. ${ }^{20}$ En último término, el utilitarismo estuvo siempre presente en el castigo, incluso antes de lo que Foucault llamaba "el interés colectivo en la pena", pues por una parte, las penas de cámara constituyeron parte del salario de los servidores del rey; por otra parte, porque los castigos que conllevaba la pena de trabajo bien en arsenales o galeras, bien en las obras públicas (por ejemplo, el Canal Imperial de Aragón ${ }^{21}$ ), beneficiaban a la colectividad; en suma, el cuerpo social aprovechaba todos sus miembros y se mostraba justificado, pues al fin todo lo actuado en cualquier tipo de proceso proviene de una autoridad delegada de Dios y del Rey. ${ }^{22}$ Mandar en el Antiguo Régimen es juzgar y se juzga desde el más pequeño delito hasta la decisión de los poderosos, todo está refrendado a la mayor gloria de Dios y del Rey, que constituyen la cima del imaginario popular tras siglos de imposición de un régimen que nunca pensó tener final.

\section{La justicia ordinaria}

El proceso judicial inquisitivo típico del Antiguo Régimen, que comenzaba con la denuncia de alguaciles, cargos públicos o particulares, tenía un sistema de pruebas basado en las declaraciones de los testigos y en las confesiones de los encausados que se realizaban bajo juramento y ante el escribano público, lo cual convertía en prueba procesal lo de que de otro modo constituiría una simple información sin valor penal ninguno. A partir de las distintas declaraciones se jugaba con las mismas para lograr ir sonsacando en las distintas confesiones la verdad de los hechos en busca de varios testimonios coincidentes, con el fin último de llegar a la prueba perfecta, la confesión de los acusados, que no siempre se juzgaba necesaria. De hecho, para que pudiera dictaminarse una condena bastaba con dos o más testimonios coincidentes, pues en muchos casos solo se pretendía exhibir el papel aleccionador y ejemplificador de la justicia. ${ }^{23}$

20. CASTILLO DE BOVADILLA, Manual de corregidores...

21. PÉREZ SARRIÓN, G., El Canal Imperial y la navegación hasta 1812, Zaragoza, 1975.

22. HERAS, J. L. de las, "Los galeotes de la Monarquía Hispánica durante el Antiguo Régimen", Studia Historica. Historia moderna, 22 (2000), pp. 283-300.

23. TOMÁS Y VALIENTE, F., El Derecho penal de la monarquía absoluta (siglos XVI, XVII y XVIII), Madrid, 1969 (1992), págs. 171-172, 176, 178, 180-181. 
A partir de la documentación analizada podemos afirmar que se cumplen los distintos casos de procesos penales establecidos por el profesor Tomás y Valiente. En primer lugar encontramos la investigación procesal que inicia el propio juez-corregidor de oficio, es decir, ante una pesquisa o una sospecha concreta el juez abre diligencias para inquirir y dictaminar la existencia del delito a castigar. En estos casos el corregidor ordena al escribano iniciar el proceso de averiguación para aclarar el delito cometido, mientras al sospechoso (casi siempre había algún indiciado por culpabilidad) se le metía en prisión y se le embargaban sus bienes. A continuación se buscaban las pruebas de culpabilidad, principalmente mediante la declaración de testigos y la confesión del preso, tras lo cual se promulgaba la sentencia. Otra fórmula era la "denunciación", que consistía en la puesta en conocimiento de la Justicia del hecho delictivo y la indicación del presunto culpable, quedando normalmente el delator en el anonimato. A partir de ese momento se iniciaba el proceso penal que mantenía las mismas características que acabamos de mencionar. Otra modalidad partía de la denuncia propiamente dicha, es decir, una parte (que puede erigirse en acusador además de denunciante) presenta una querella por el delito cometido contra una persona a la que se le acusa del mismo, tras lo cual la justicia iniciaría una vez más con los mismos métodos la investigación de la causa.

Una de las peculiaridades más notables de la justicia del Antiguo Régimen lo constituye el hecho de que algunas de sus actuaciones eran difícilmente evitables, tanto para los culpables como para los inocentes encausados. Nos referimos a la prisión previa a la sentencia (de duración variable), así como a los embargos, que repercutían directamente en la "honra" y en la economía, lo que constituía en ocasiones un verdadero estigma para los reos y sus familias y un problema para su subsistencia. La prisión, sin embargo, era concebida como custodia y no como castigo, pues con ella se pretendía facilitar la investigación, los interrogatorios y la confesión del acusado, además de preservarle de la violencia de los afectados o de la muchedumbre ante el generalizado sentido popular del derecho de venganza, sobre el que se sobreimponía la Justicia Real, representada en este caso por el corregidor y las autoridades de la ciudad. ${ }^{24}$

Pero son muy frecuentes los casos en los que el sospechoso encarcelado se queja amargamente de las insalubres condiciones en las que vive en la prisión, y es que en las cárceles de la época los prisioneros sufrían todo tipo de incomodidades y carencias, casi todas ellas emanadas de la falta de higiene y el hacinamiento. Además, en la mayoría de los casos tratamos con gentes humildes que no poseen grandes recursos, por lo que sus familias son incapaces de mantenerles. A veces encontramos declaraciones de estos pobres desgraciados del tenor de la siguiente: "hace cerca de dos meses que me hallo en dicho calabozo,

24. PEÑA MATEOS, J., "Antecedentes de la prisión como pena privativa de libertad en Europa hasta el siglo XVII" en GARCÍA VALDÉS, C., Historia de la prisión..., op. cit., p. 53. 
cerrado con grillos, sin cama más que un costal con paja, acosado de ratas y ratones, lleno de hambre y necesidad". ${ }^{25}$

Como es sabido, la situación de los establecimientos penitenciarios era muy precaria en casi todas las ciudades. Sorprende que no haya siquiera una atención a la necesidad de alimentarse y que los presos vivan de la caridad pública. Ésta es también una de las razones por las que a veces se les da también por cárcel su casa y que salir de la cárcel no sea en ocasiones considerado una fuga. Hay pocas fugas, puesto que no pueden ir a ningún sitio donde no sean conocidos, y saben que agravarían la pena. Han de pasar portazgos en cada ciudad o pueblo por donde vayan, se les pedirán pasaportes y su propia indumentaria les delatará. Por eso, pueden salir de la cárcel para volver a ella, generalmente para alimentarse. En muy pocas ocasiones hay fugas organizadas. Veamos un ejemplo, que nos permite además conocer la cárcel de la ciudad por dentro. Varios presos han abierto una brecha en la pared y han forzado cerrojos, pero no todos han querido huir; la mayoría se ha quedado dentro. El regidor preeminente en ausencia del corregidor inicia el proceso de investigación y se pone al frente de la tropa que va a asegurar a los presos que permanecen en la cárcel. El "rompimiento de la pared" había ocurrido el día 31 de enero de 1783, a las 9,30 de la tarde, y a las 12 , ya estaba la tropa vigilando y el regidor y el escribano tomando declaraciones. Los testigos dicen que se llegaron a juntar unos veinte presos "a beber y jugar" en las habitaciones de arriba, mientras fue "abajo" donde se limó el cerrojo y se abrió el muro. Un reo al que se le imputa un asesinato en Lanciego dice que ha estado "bebiendo y jugando con motivo de habérseles dado de limosna". Delata a tres presos. Son las dos de la mañana y el alcaide dice que puede haber peligro, pues se han encerrado en una habitación los más peligrosos. Se deja la toma de declaraciones y se quedan los soldados vigilando. Al final, el juez desiste y el proceso se abandona. ${ }^{26}$

En estas condiciones se veían todo tipo de presos, desde los asesinos convictos a los que simplemente habían participado en acciones violentas, o eran sospechosos de riñas y pendencias. Todos piden salir, que se les dé por cárcel su domicilio, pues son necesarios para mantener a la familia. A veces, solicitan salir incluso aquellos que eran denunciados por faltas en el terreno del honor en el trato con mujeres, como ocurre, por ejemplo, con Nicolás Lezana, acusado de haber abusado y haber dejado preñada a Saturnia Azcárate. ${ }^{27}$ A través de su procurador, el preso pide salir de la "dilatada prisión", pues la mujer ya sabía que "se halla casado, cuya circunstancias es muy atendible para la soltura". Fiel a la tradición, el reo acusa a la mujer "cuan más delito debió cometer la susodichas en arrojarse a un hombre ligado que no podía llevarla así con palabra de

25. AHPLR, judicial caja 935/2, año 1789 .

26. AHPLR, judicial caja 888-7, año 1783. Sobre las cárceles, véase FRAILE, P., Un espacio para castigar. La cárcel y la ciencia penitenciaria en España (siglos XVIII-XIX), Madrid, 1987.

27. AHPLR, judicial caja 890/2, año 1781. 
matrimonio"; incluso se permite dar lecciones: "a semejantes mujeres no se les debía oír en términos que aquí se experimenta", pues él "no sólo es inocente, sino que ella ha vivido libre sin sujeción a persona alguna y pasando las noches en establos abandonados y soportales". Más adelante llegará a pedir su puesta en libertad bajo fianza alegando que no tenía su familia ni comida que llevarle a la cárcel, sin embargo, el corregidor le condenó a mantener a Saturnina y a su supuesto hijo.

La solicitud de libertad casi siempre es originada por la necesidad de que el preso trabaje para mantener a la familia. Veamos este caso: "En el día de ayer se tomó nuestras confesiones en las que hemos manifestado la verdad, y hallarnos inocentes de lo que se nos imputa, en cuya atención y en la de que, como expusimos en nuestro primer prendimiento hacemos suma falta en nuestras casas para atender a nuestras familias que se hallan pareciendo de necesidad por consistir su alimento en nuestro trabajo al oficio de labradores braceros, sin otro arbitrio. Suplicamos a vos se sirva mandar se nos suelte libremente sin costas de la referida prisión, sobre que imploramos la piedad de vuestra señoría". ${ }^{28}$

De una manera excepcional, pero periódicamente recurrente, encontramos otro argumento de autoridad por el que los encarcelados imploraban su puesta en libertad antes de la sentencia definitiva: de una manera sutil pero certera, alegaban la cercanía de fechas clave como la "de las próximas Pascuas de Nuestro Redentor Jesuchristo, y su Sacrosanta Natividad"; en otros casos era el propio corregidor quién consciente de la magnanimidad que de él se esperaba alegaba: "en atención a las presentes Pascuas del Nacimiento de Nuestro Redentor Jesucristo....". ${ }^{29}$ La acusada en el caso también pide perdón públicamente por haber agredido a su vecina. Puede que hoy en día nos sorprendan éstas vinculaciones con la religiosidad, pero al fin y al cabo el corregidor es el juez representante de un Rey Católico que se debe a Dios, además, incluso hoy en día se mantienen estas ideas de una manera residual en algunos actos de la Semana Santa, como es el tradicional indulto que se suele conceder a un preso, o incluso el mantenimiento de privilegios concedidos por los reyes a cofradías o hermandades que pueden por ello ejercerlo y libertar a alguno de los penados. ${ }^{30}$

Estas apelaciones son generalizadas entre todo tipo de presos, sin embargo, en pocas ocasiones son liberados sin mayores consecuencias, pues por norma general se les impone una fianza. Curiosamente este procedimiento parecer ser de lo más aceptado, pues salvo alguna excepción, siempre se hace alusión a ella. Unos como ofrecimiento de buena voluntad en un claro intento de apelar a la clemencia del corregidor, así llegan a pedir su libertad "bajo de fianza car-

28. AHPLR, judicial caja 107-14, año 1767.

29. AHPLR, judicial caja 76/5, año 1776.

30. GÓMEZ URDÁÑEZ, J. L., La Hermandad de la Sangre de Cristo de Zaragoza: caridad y ritual religioso en la ejecución de la pena de muerte, reed., Asociación para el Estudio de la Semana Santa, Zaragoza, 2004. 
celera, que estoy pronto a dar"; son excepcionales los casos en los que se pide la libertad sin ésta, como el del platero Antonio San Román: "a lo menos bajo de caución juratoria sobre que implora piedad", pues considera que su culpa ha sido leve, y otros, con la misma intención, sacan a relucir su situación extrema como afirma el procurador de Santiago Cabredo: "se le suelte de dicha prisión bajo de caución juratoria, respecto de que por su pobreza no tiene arbitrio para dar fianza alguna". ${ }^{31}$ Aunque no siempre se aceptaban estas peticiones, generalmente suelen ir acompañadas de la pena (costas, perdón público...), pero en delitos graves o protagonizados por vagos, gitanos o contrabandistas se les deniega toda posibilidad con el mayor rigor para enviárseles a las cuerdas de presos que les llevaban hasta los arsenales de la marina o los presidios de África en los casos en que hubieran sido condenados a trabajos forzados. Esto se debe a que la fianza se otorgaba a los reos encausados por delitos con penas pecuniarias, de esta manera podían ser liberados de la cárcel en la fase terminal del proceso judicial, generalmente tras la confesión, tras lo cual se encontrarían a la espera de la sentencia definitiva. Aunque no hemos podido constatarlo en la mayoría de los casos, como demuestran otros estudios similares, debía existir un fiador que respondía por el fiado ante la Justicia, comprometiéndose a garantizar su presencia en el momento de emitir la sentencia.

Tras la fase probatoria se pronunciaba la sentencia, que como hemos podido apreciar, y como ya señaló Tomás y Valiente, no se fundamentaba en hechos reconocidos ni en pasajes concretos del Derecho vigente, predominando sentencias lacónicas simplistas. En estas cuestiones reside la autonomía de los jueces a la hora de impartir Justicia, traduciéndose las sentencias en "simples y escuetas declaraciones de voluntad, carentes de explicación y de justificación". 32 Así, hay que extrapolar e incluso imaginarse las motivaciones y pruebas que han llevado al juez a dictaminar su resolución, lo que nos hace pensar que, en definitiva, la justicia tenía fuertes dosis de arbitrariedad y el juez se dejaba llevar por las circunstancias, no sólo del caso, sino de las consecuencias, que podían variar entre la ejemplaridad, la dureza, o el paternalismo clemente, en definitiva, una didáctica o incluso una advertencia, como prueba el siguiente ejemplo: “...debía apercibir y apercibo a la referida Jacinta que en adelante se abstenga de injuriar verbalmente a la dicha Joaquina con palabras iguales a las que ha sido procesada ni otras algunas, viviendo con la paz, unión, razón y armonía que corresponde entre cosas tan propias, sin dar luego a semejantes criminalidades so pena de ser castigada con el mayor rigor, y por esta vez se la condena en las costas de esta causa a justa tasación y en dos sueldos de multa aplicados a penas de Cámara y gastos de Justicia por mitad con que se da". ${ }^{33}$

31. AHPLR, judicial caja 76-10, año 1787-1788.

32. TOMÁS Y VALIENTE, F., El Derecho penal..., Madrid, 1969 (1992), pp. 181-182.

33. AHPLR, judicial, caja 894-10, año 1784. 


\section{La violencia latente: injurias, riñas y robos}

Las agresiones en el seno de la familia son las más frecuentes si consideramos la familia extensa, es decir, la que incluye cuñados, cuñadas, nueras, sobrinos, primos, etc. Las relaciones sociales tenían una estructura vertical, que se apoyaban en el "dominio y sujeción consentida" ${ }^{34}$ en la que primaba el dominio del varón sobre la mujer, ya fuera el padre sobre la hija o el marido sobre la esposa, lo que el juez solía recordar con frecuencia. La familia sustentaba todo el entramado social del Antiguo Régimen, por lo que "la máquina administrativa de la monarquía la apoyó plenamente durante todo el período moderno". ${ }^{35}$ De esta forma, el padre era el encargado de cuidar y mantener el buen nombre de la familia. Por su parte, las mujeres eran las transmisoras del linaje y, por tanto, del status social de las familias, de ahí el férreo control que se ejercía sobre ellas: a algunas doncellas se las aislaba en sus domicilios para evitar dudas sobre su honestidad y su virginidad, así como para garantizar la legitimidad de los hijos, incluso se las ingresaba en conventos para aumentar la dote de las otras hijas, etc. ${ }^{36}$ Cuando se intuía alguna desviación moral de las doncellas o esposas, se pasaba a utilizar la fuerza y la violencia, un mal menor, tanto a ojos de la sociedad como de la Iglesia; pero cuando se llegaba a las agresiones, se entendía que era un exceso nada conveniente, por lo que actuaba la justicia. Como ha dicho el profesor Mantecón, "La violencia física era un eficaz instrumento para estrechar fidelidades, era realmente una posesión inmaterial, materialmente proyectada, decisiva en las relaciones sociales y nítidamente percibida por personas y familias. Era un componente esencial de la tensión que subyacía a un orden reequilibrado cotidianamente" ${ }^{37}$

Pero la violencia no sólo era física; el lenguaje podía herir con la misma violencia, o ser el desencadenante. Es lo que ocurrió en la riña entre dos primos porque uno le había dicho al otro que su mujer "no tenía bastante con cuatro hombres". ${ }^{38}$ Ante la injuria, reaccionó el primo insultado, que una vez denunciado, fue conducido a la cárcel. El caso se sustanció, como solía ser habitual, con la petición de perdón y el juramento de que no se volverían a repetir los hechos.

34. MANTECÓN MOVELLÁN, T., "Desviación, disciplina social e intervenciones judiciales en el Antiguo Régimen", Studia Historica. Historia moderna, 14 (1996), p. 227. Sobre la familia y su importancia, véase SOUBEYROUX, J. y FERNÁNDEZ, R. (coords.), Familia y clases populares en España (siglos XVIII-XIX), Lleida, 2001.

35. ORTEGA LÓPEZ, M., "Violencia familiar en el pueblo de Madrid durante el siglo XVIII", en Cuadernos de Historia Moderna, no 31 (2006), Universidad Autónoma de Madrid, Madrid, p. 8.

36. LORENZO CADARSO, P. L., "Los malos tratos a las mujeres en Castilla en el siglo XVII", en Brocar: Cuadernos de investigación histórica, nº 15 (1989), p. 121.

37. MANTECÓN MOVELLÁN, T., "Desviación, disciplina social e intervenciones judiciales en el Antiguo Régimen", Studia Historica. Historia moderna, 14 (1996), p. 234.

38. AHPLR, judicial, caja 888-4, año 1784. 
Reconciliados ambos, que no olvidemos es lo que busca la justicia, el agresor salió de la cárcel.

Este tipo de actos se producían con mucha frecuencia, pues la estrechez de la casa habitación, el hacinamiento de varias familias en casas de pisos, donde las hay que solo tienen un cuarto para todo, en fin, la pésima situación de muchas viviendas logroñesas producía constantes roces y disputas. Es el caso de la riña entre dos familias que comparten la misma vivienda, una de ellas alquilada. La casera quiere cerrar la puerta de la calle, pero la familia Manteli se lo impide, pues el clarinero Antonio Manteli se encuentra en la casa de enfrente jugando a las cartas. La casera aduce que ya la noche anterior se había quedado abierta e, inmediatamente, estalló la riña con insultos del tipo "galopina, bribona", etc. Las voces alertaron a Antonio Manteli, quien fue recibido con golpes contra las paredes hasta que terminó derribado de un garrotazo dado por Juan Rodríguez, el casero ${ }^{39}$.

El juez condena al casero al pago de las costas y a sufragar la curación del clarinero, pero el condenado Juan Rodríguez se siente agraviado, pues considera que el culpable es Antonio Manteli y apela a la Real Chancillería de Valladolid, lo que no era nada frecuente: "A Vuestra Señoría, se sirva admitirme la apelación que llevo interpuesta en estos efectos, y que para mejorarla se me dé el correspondiente testimonio; pido Justicia con costas y Juro etc." ${ }^{\prime \prime 0}$

A veces las riñas eran muy aparatosas y congregaban a varias familias y vecinos, pero ni así se apelaba, toda vez que se sustanciaban con el pago de costas tras el ofrecimiento de perdón y cada uno a su casa, siempre desconfiando de la justicia y temiendo que pudiera ser peor. Un caso entre tantos puede ser la trifulca que protagonizaron María Corona y Vicenta González, que se enzarzaron en una pelea "con grandes y crueles azotes" hasta el punto de que "la hubiera quitado la vida de no intervenir el resto de vecinas". Todo ello se inició por el gato de María Corona, a quien acusa Vicenta González de comerle las ollas, por lo cual, le tiró "un palito". ${ }^{41}$

El lugar de trabajo, los campos y huertas o los talleres de los artesanos, eran también escenario de frecuentes riñas, como la que se produjo en 1771 en una era en la que trillaban, entre otros, los criados de los dominicos del Convento de Valbuena. Uno resultó herido a causa de "navajada" que le dio por detrás un criado de los frailes que, luego, se acogió a sagrado en el convento. Interviene el cirujano Juan Delhuyar, que hace una perfecta descripción de la herida, que según el, es "mortal de necesidad", pues ha interesado a los intestinos, aunque luego resultó que le herido se restableció. El corregidor dicta orden de prisión contra el autor, al que no encuentran. Los testigos dicen que sigue refugiado en el convento.

39. AHPLR, judicial, caja 76-10, año 1787-1788.

40. AHPLR, judicial, caja 76-10, año 1787-1788.

41. AHPLR, judicial, caja 76-10, año 1787-1788. 
El crimen ha sido a fines de agosto y el autor aparece en diciembre diciendo que se había ido a trabajar fuera de Logroño para mantener a su familia. Ha entrado voluntariamente en la cárcel y pide indulto a través de procurador, que se le concede aprovechando que es "la festividad del Nacimiento de Nuestro Señor Redentor Jesucristo". Un año después, el herido que se declara pobre de solemnidad, dice que estuvo curándose en el Hospital y que los gastos fueron crecidos, por lo que pide que corra con ellos el autor. Dice que no lo pidió antes por no saber. Pero la respuesta del corregidor es fulminante: no ha lugar. La causa es que la estancia en el hospital no le acarreo gasto alguno, pues le curaron de limosna. El caso se cierra sin más. ${ }^{42}$

A veces el campo es el escenario de violencias de índole familiar, o sexual, como es el caso de la que sufrió Teresa González, que se querella contra Martín López porque estando en el melonar de su yerno, Blas de Ortigosa, la abordó diciendo que es "una desollada, picarona y lerdísima puta", lo que repitió muchas veces, y luego añadió que es una "ladrona, que le ha quitado las alubias de una pieza". La sentencia del corregidor condena a Martín López a las costas y a la restitución pública de "la buena fama, honor y predicamento" de la injuriada. ${ }^{43}$

Son tan frecuentes estas riñas como las que se producen por el agua. Las fértiles huertas de regadío dependían de los turnos establecidos para regar. Podía ocurrir que un labrador con huertas más arriba que las del que le "tocaba el agua", se la "quitase", lo que provocaba constantes riñas, congregando a varios vecinos. Uno de tantos casos es el que ocurrió cuando varios hombres golpearon a los de José Espinosa que se hallaban regando en Puente Madre, barrio de Villamediana, para quitarles el agua y regar sus tierras. Según palabras de los agresores, tuvieron que pegarles porque "se dejaban caer mucha agua perdida a la Iregua". ${ }^{44}$

Entre los artesanos, hay frecuentes casos. Veamos uno como ejemplo. José Joaquín de Lara, albañil, denunció a tres trabajadores que, tras burlarse de él, comenzaron a pegarle y terminaron por empujarle, con tan mala fortuna que acabó cayendo sobre uno de los sillares que estaban empleando en la construcción de una vivienda. José Joaquín resultó con "una costilla hundida y otra resentida y varias contusiones". Los agresores fueron conducidos a prisión y cargaron con las costas y los jornales que el agredido no pudo cobrar al encontrarse indispuesto para el trabajo. El propio José Joaquín declaró, cuando sus lesiones ya había curado, que perdonaba a los tres acusados por sus burlas y por sus golpes ${ }^{45}$.

42. AHPLR, judicial, caja 2-6, años 1771-1773.

43. AHPLR, judicial, caja 76/18, año 1777.

44. AHPLR, judicial, caja 76/14, año 1775.

45. AHPLR, judicial, caja 76/13, año 1776. 


\section{Pobres, privilegiados y... mala raza}

En estos casos de roces de vecindad, el interés no está en el caso en sí, pues suelen ser todos muy parecidos, sino en la capacidad que tiene el tratamiento judicial de desvelar comportamientos característicos de la sociedad de los privilegios, que son obviamente esgrimidos en el mundo de la justicia por aquellos que los detentan. Veamos un caso de aparente imposición por parte de un rico hidalgo logroñés, Nicolás Bernabé de Bendígar, que además es regidor perpetuo, contra un labrador que parece estar indefenso ante la denuncia y sufrir una pena desproporcionada. Es julio de 1736, cuando el hidalgo denuncia que un vecino ha entrado con tres caballerías en su tierra, en Cascajos, "derribando cepas y pulgares", por lo que pide nada menos que lo metan preso en la cárcel y que un perito tase los daños. Ha roto 36 pulgares, según la peritación. El vecino parece que salía con cargas de mies varias veces por el majuelo.

A pesar de que el daño no es mucho -cada cepa podía tener entonces hasta una docena de pulgares- el corregidor manda que el vecino y su criado vayan a la cárcel y se les embarguen los bienes. El pobre Felipe de Abalos, que es el labrador, dice cuando ya "hace muchos días se halla en dicha cárcel", que ni siquiera fue él el que pasó por la propiedad del regidor, sino que fue su criado. Luego, se refiere a "la suma falta que hace en su casa para recoger su agosto que lo tiene crecido" y a que por el mismo sitio que él han pasado otros vecinos.

Al final, lo sueltan y le condenan a pagar los daños, que solo ascienden a 21 reales en total. Como es costumbre, el corregidor le ordena que no vuelva a pasar o será condenado con mayor rigor. Pero además le condena en costas, 67 reales, y le pone una multa de 1.400 maravedís. Evidentemente el demandante era noble y había logrado dar un escarmiento, a pesar del escaso daño que habían sufrido sus cepas. ${ }^{46}$

A veces, el privilegio era precisamente el que llevaba aparejada la autoridad, aunque solo se tratase de un alguacil. En el siguiente caso, la autoridad es la del alcalde de barrio, al que parece haber injuriado Baltasar Zenzano, que se atrevió a sacarle la espada "y amenazando a dicho alcalde que le había de embasar con ella, que era un galopín, que no merecía ser tal alcalde de barrio". La ronda está a punto de prender al autor, pero huye y solo cogen a un compañero, "El Chorrillo". Poco después, apresan al autor y lo meten en la cárcel. Así, por su declaración sabemos que es un labrador con mujer e hijos y dice que lo hizo "con ingenuidad". Sin embargo, el corregidor le sentencia amenazando con que si hay reincidencia le pondrá la pena prescrita para los que no respetan a las autoridades y que es nada menos que cinco años en el servicio de las armas y arsenales. Por ser la primera vez y siendo benigno el juez, le multa a 6 ducados y pagar las costas. ${ }^{47}$

46. AHPLR, judicial, caja 139, 6, año 1736.

47. AHPLR, judicial, caja 888-5, año 1784. 
Pero no siempre los que comparecen ante el corregidor son los pobres, los vagos o los jornaleros, o las mujeres del más bajo nivel; pues excepcionalmente, encontramos también algún caso en que la ira y la rabia afloran entre los miembros de la oligarquía logroñesa. Se trata quizás de viejos enfrentamientos, pero rara vez se dirá el motivo y, por lo general, todos contribuirán a que pasado el momento de la cólera inicial el asunto se dirima entre llamadas a la reconciliación y olvido de los agravios. Seguramente hasta una nueva ocasión.

Uno de estos casos es el que protagoniza María Salomé Santacruz, hija de Domingo Santacruz, un rico hacendado logroñés, cabeza de una saga que después de la guerra de la Independencia será la familia más rica de Logroño. El agraviado es nada menos que Pedro Gabriel de Covarrubias, escribano de la bien conocida saga logroñesa, que reconoce ser "quieto, pacífico (...) aplicado incesantemente al ejercicio de la pluma", que como podemos comprobar en los centenares de protocolos que redactó, con letra clara y buena ortografía, ejerció con brillantez. Covarrubias, siendo joven, se querelló contra María Salomé, pues ésta le increpó en el paseo, en el camino de Varea, cuando se cruzó con ella, yendo en compañía de su hermana. Según declaró el escribano, María Salomé, que estaba en compañía de otras dos mujeres, tras "saludarla mi hermana con la expresión cristiana de que fueran con Dios", arremetió "llevada de su genio audaz y quimérico con voces las más altas y desentonadas" contra Covarrubias, a quien le dijo que "fuésemos con cinco mil demonios" y "piazo bribón que campaba con lo que era suyo y que habiéndome presentado en juicio verbal ante Vuestra Señoría (el corregidor) sobre que declarase si la debía cien pesos, juré en falso, que la pagase lo que le debía". Aparece el agravio y, además, no es la primera vez, pues un año antes, también en un paseo público, se habían producido hechos similares, según declara Covarrubias. Todo ello llevaba al querellante a vindicar su honor "y precaver en lo sucesivo iguales denigraciones y ofensas". Y en efecto, eso es de lo que se tratará en adelante, de reducir el asunto solo a los insultos, lo que vendrá favorecido por las declaraciones de los testigos, que recogen también las expresiones insultantes vertidas por Covarrubias en sus respuestas a la mujer. Así, una de las acompañantes de María Salomé, esposa de un sargento del Regimiento de Milicias de la ciudad, dice que la hermana de Covarrubias contestó a los insultos de María Salomé: "todo esto, señores, es porque esta señora anda recalentada con mi hermano". Covarrubias, además, habría añadido al responder a la solicitud de que pagará lo que debía: "si te hubiera pedido otra cosa también me la hubieras dado, que quieres marido".

Y hasta aquí llega el expediente. Ni siquiera constan las declaraciones de otras personas implicadas en la riña, que sabemos que no pasó de las palabras. Sin duda, las familias arreglaron el problema en privado, librando por otra parte al corregidor de intervenir en estos asuntos entre familias ricas, que sabía que podían acarrearle problemas en sus años de estancia en la ciudad. ${ }^{48}$

48. AHPLR, judicial, caja 894-9, año 1784. 
En el mundo eclesiástico, el privilegio conllevaba también la exigencia de respeto, como prueba el caso de Manuel Barcina contra el presbítero beneficiario de la Imperial de Palacio, don Baltasar Ambrosio de Bustamante y Loyola, al que acusa de ser "cura de los demonios", tal y como se recoge en el auto de oficio abierto por faltar "a la veneración y respeto que se debe a el estado eclesiástico". El dicho Manuel "tomó del suelo un canto y con él llamó con grande furia en la puerta y habiendo abierto se entró y empezó a subir las escaleras diciendo que aunque lo ahorcasen había de hacer y contecer con el dicho don Baltasar". Allí encontró al sacerdote cuando marchaba a oficiar las vísperas. El motivo de la disputa parte de una notificación que el regidor de campo había entregado a Manuel Barcina por la cual debía pagar una renta por una huerta que tenía en usufructo de la iglesia Imperial de Palacio. Indignado por ello y en estado de embriaguez, acudió en búsqueda de don Baltasar, "eclesiástico, virtuoso y muy compuesto, enemigo de quimeras, y que en su estado y calidad se le debe mucha veneración y respeto".

Como se ha vulnerado el respeto a un estamento privilegiado, el fiscal afirma que "se debe condenar al susodicho en las mayores y más graves penas dispuestas por las leyes de este reino"; incluso le acusa de profanar "la casa de tan gran caballero causando notable escándalo en su estado y juramentos". Finalmente, teniendo en cuenta sus alegaciones -larga prisión de quince días, papel necesario como hortelano para su familia y petición de libertad bajo fianza-, el corregidor dictamina que "le debo condenar y condeno en cuatro mil maravedís aplicados por mitad Cámara de este y gasto de Justicia, y en las costas causadas y que se causaren hasta la execución de esta mi sentencia (...) y le apercibo y mando que en adelante se abstenga de cometer semejantes excesos tratando con todo respeto y veneración al estado eclesiástico pena de seis años de destierro de esta ciudad y su jurisdicción y de diez leguas de contorno, la que se executará y inviolablemente y de procederse a lo demás". 49

Pero lo más general es ver a los pobres ante la justicia, pobres e ignorantes y a veces todavía sometidos a los prejuicios de la marginación individual y la afrenta de la mala raza. A veces, la documentación permite conocer situaciones de pobreza agravadas por la desenvoltura entre mujeres de la calle, que llegan a insultarse por su raza, o por el recuerdo de ser procedente de judíos. En 1799, Eufemia Medrano, de Lardero, denuncia a María Santos, por haberle dicho delante de varias personas, que "era una alcahueta de criados de servicio, que su raza o generación no había dado tanto que hablar ni decir como la mía, y añadiendo injuria a injuria y baldón a baldón, profirió igualmente la execrable de que era una judía, expresiones todas ellas de las más horrendas y graves".

Declara una testiga y dice que Eufemia comenzó diciéndole a la otra: "grandísima enredadora, bribona, que te temo la salvación (sic), María Santos le dijo más eres tú" y así hasta llegar al siguiente diálogo entre una y otra: "En todos los

49. AHPLR, judicial, caja 96-2, año 1730. 
montes que nieva, no cuaja.- En esta caldera aunque nieve no puede cuajar.¿Me has visto a mí? - Porque en ti aunque cuaje no se te puede notar porque tienes marido y a mi si me sucediera sí, porque no lo tengo.- Yo cuando me casé lo llevé entero.- Mujer, no seas judía". ${ }^{50}$

En otro caso, en 1765, el recuerdo de la "mala raza" va más allá. Dos mujeres riñen en la calle y una le dice a otra "que era ladrona y puta", según declara la afectada, sin motivo. Declaran los testigos que hubo más palabras como mujer corrida, corremundos, picarona, de mala secta, reputa, etc. El corregidor manda embargo de bienes, que ejecuta el alguacil y notifica el auto de prisión, pero "le da su casa por cárcel". Pero declaran los testigos y el abogado de una de ellas dice que entre las injurias, le dijo "Vete a ver los papeles que tienes en la Redonda, significando esto que mi parte es de raza de judíos o penitenciados por el Santo Oficio de la Inquisición, supuesto que en ninguna iglesia de esta ciudad sino que sea en la redonda hay rótulos de judíos y penitenciados" ${ }^{51}$

\section{Ladrones, vagos, malentretenidos y contrabandistas}

El tratamiento judicial de los delitos contra la propiedad suele reflejar más severidad y menos paternalismo. El propósito del juez no es sólo restituir la paz social, aunque puede contentarse con ello si el delito es de menor cuantía y ocasional, o lo que es más importante, si no constituye una prueba de conducta habitual delictiva. En caso contrario, las penas suelen ser muy severas y, desde luego, no suele haber burlas como las que reflejan algunas obras de la literatura picaresca, como nuestro Guitón Onofre, ${ }^{52}$ la tercera novela picaresca española por cronología, escrita por un riojano. En el siglo XVIII los casos que se presentan ya no son los de los pícaros que mueven a burla, sino los de gente obligada a robar a veces desde niño, pero sin que haya asomo de comprensión por sus fechorías, que siempre se suelen exagerar invocando que pueden ser incorregibles y que, sobre todo en el caso de los niños, han caído ya en la "mala vida" y la "inclinación por el mal". No encontraremos en los procesos ningún argumento sobre el origen social del delincuente, el agravante de la pobreza y la necesidad, o la soledad y el abandono de los niños delincuentes.

A diferencia de las riñas e insultos y precisamente por la severidad de las penas, en robos y hurtos es mucho más difícil llevar a los sospechosos a confesar la culpa, incluso contando con la cárcel. Por eso, a veces, sospechosos inocentes resultaban castigados. Veamos un caso. Un vecino denuncia el robo que ha sufrido José González, "que Ilaman el aguardentero". Le han robado de su casa, molino y trujal, que lleva a renta y es propiedad del cabildo de Santiago "una

50. AHPLR, judicial, caja 139, 12, año 1799.

51. AHPLR, judicial, caja 2-7, año 1765.

52. GONZÁLEZ, G., El Guitón Onofre, Edición de Fernando Cabo Aseguinolaza, Logroño, Gobierno de La Rioja, 1995. 
porción de dinero". Declarando ante el juez, dice que son cuatro los autores y que le han robado 40 pesos que tenía en casa (unos 600 reales, una cantidad estimable que superaba lo que podía ganar un jornalero en un año). Dice que sabe que han ido luego a Navarrete, a "la fiesta de novillos" y cree que jugarán con el dinero robado, por lo que el corregidor manda que se escriba una carta al alcalde de Navarrete "para que reconozca si alguno de ellos o los cuatro acuden a juegos públicos y secretos". ${ }^{53}$

Siguiendo con robos a las propiedades del cabildo, en este caso del de San Bartolomé, acusan a Tomás García y Manuel Caro, vecinos de Villamediana de Iregua, sobre extraer piedra de la ermita de Nuestra Señora de la Cuesta, quienes reconocen que "Don Juan Manuel de Muro, cura de la iglesia de dicho lugar y abad de la confradia de San Christobal, le dijo al que declara como portero que es de dicha confradia fuese a ayudar a cargar unas piedras de la hermita de Nuestra Señora de la Blanca, para llevarlas a la hermita de San Christobal", ermita que estaba en construcción. Finalmente, fueron condenados a pagar el precio de la piedra. $^{54}$

Una vez apresados los cuatro, Chomín el hijo del Bastero, Marrajo, Flojuelo el hijo del tejedor y otro llamado Corrusco, encarcelan también a Tomás Lizondo, el bastero, que como todos, declara no ser autor. Hay otros encarcelados, pero no sale la verdad. Uno de ellos es Lucas Millera, menor de edad, inocente, que dice además que "hace mucha falta para la manutención de sus padres", y que "por su pobreza no encontrará quien le salga a fianza alguna". Al final, no canta ninguno de los cuatro jóvenes ni aparece el dinero, pero el corregidor dicta sentencia el 3 de septiembre, dos semanas después de haber entrado en la cárcel los muchachos. Sin confesión no se les puede mantener más en prisión y además no hay pruebas. Por eso la sentencia es "sobreséase en estos procedimientos y apercíbase...". En el apercibimiento, el juez se esmera y les hace prometer que no irán a fiestas, que no jugarán juegos prohibidos y que observarán una vida de trabajo, honrada, sin ir a tabernas, etc. "Atendiendo a ser pobres" se les condena a la mitad de la costas: 128 reales en total. Jóvenes y pobres, han sido confundidos con delincuentes y castigados con la cárcel. ${ }^{55}$ Sin embargo, el juez se parapeta tras su discurso sobre la buena conducta que deben observar y olvida la pena de prisión sufrida por los inocentes, lo que demuestra que la Justicia tenía una libertad total a la hora de actuar. ${ }^{56}$

Pero no es lo habitual. Ni sólo era el juez el encargado de "educar". Un ejemplo real de pícaro es el de Marcelino Tobía, de 15 años y natural de Laguardia, aprendiz de sastre en casa de José Almarza en Logroño. Con el pretexto de que su maestro le solía mandar a comprar telas, aprovechó para dejar a su cargo

53. AHPLR, judicial, caja 76, 23, año 1775.

54. AHPLR, judicial, caja 2/8, año 1779.

55. AHPLR, judicial, caja 76, 23, año 1775.

56. TOMÁS Y VALIENTE, El Derecho Penal..., pp. 171-172, 176, 178, 180-181. 
varias piezas por valor de 136 reales y 12 maravedís "sin su consentimiento" para venderlas a lo largo del Camino de Santiago hasta Burgos. Finalmente, es el propio maestro José Almarza el que se hace cargo de pagar a los vendedores y así sacar al niño de la cárcel, pues se entiende que el maestro ha de cuidar de la educación del aprendiz y en este caso, del castigo. ${ }^{57}$

Otro caso de niños delincuentes corregidos -y en este caso con gran severidad- es el de tres muchachos que "andan vendiendo unas alhajillas de Plata de las que sirven para el Santo Sacrificio de la Misa"; son José Dezía, Roque Fernández y Manuel Vicente de Heras, los dos primeros, vecinos de Logroño, de 11 años, ni tan siquiera han hecho la primera comunión; el tercero, de 13 años de edad y que aunque tiene licencia de comulgar no lo ha hecho hasta ahora, es natural de Elciego. Manuel Vicente de Heras, el cabecilla, se encontró con los dos niños en la calle Portales de Logroño y los indujo a ayudarle a vender la plata que tenía, a lo cual "los declarantes aceptaron, pues se hallaban ambos sin tener qué comer". Estos indicios parecen corroborarse con el historial delictivo que arrastra el citado Manuel, tal y como recoge el joven José en su declaración: "Preso en Briñas mes y medio, y en Ábalos dos días, y que en Uruñuela ha untado a el estanquero que Ilaman Chavaque cien reales, y que habiendo salido en su busca lo cogieron y se los quitaron como también una coletilla y una montera suya; lo cual sabe por habérselo dicho el mismo Manuel Vicente de Heras". A pesar de su edad, los tres dan el tipo de vago que acaba en los arsenales. Y así ocurrirá.

El corregidor abre diligencias de oficio para averiguar de qué iglesia han sustraído la plata; extrema la gravedad, pues hay delito de sacrilegio, y anuncia que será severo en las penas "para que a ellos sirva de castigo y a otro de enmienda". ${ }^{58}$ Los dos más pequeños no participaron en el robo, puesto que ninguno conoce la procedencia de la plata, más allá de la vaga idea que parece tener José, que declara que Manuel se la había quitado al sacristán de Viñaspre. Además, Manuel declaró que se encontró con un muchacho de San Millán, del que sólo sabe que se llama José, y juntos entraron en la iglesia logroñesa de San Blas, donde sustrajeron los artículos robados del altar de Nuestra Señora de los Desamparados.

Tras prestar declaración el rector y beneficiario de la iglesia de San Salvador y San Blas, el corregidor ordenó buscar a todos los receptadores, a quienes metió en prisión y ordenó que se les embargaran los bienes y que se le entregaran todos los artículos sustraídos, incluso los que ya habían sido devueltos a los responsables eclesiásticos de San Blas. La investigación sigue inalterable su curso y se descubren más antecedentes del joven Manuel Vicente Heras, aunque sólo reconoce un caso en el que vendió una cruz y unos pendientes de plata utilizando como vendedora a la madre de José Decía, con lo que ganó 13 reales. Este hecho es corroborado por Teresa Gómez, quién en su defensa alega que al enterarse

57. AHPLR, judicial, caja 76/6, año 1773.

58. TOMÁS Y VALIENTE, F., El Derecho Penal de la Monarquía Absoluta (siglos XVI, XVII y XVIII), Madrid, 1992, p. 248. 
de que pertenecían a su vecina Ventura Martínez Chacón se los devolvió, tras pedírselo a otra vecina a la que se lo había vendido, cruz que es aportada como prueba por la dicha Ventura ${ }^{59}$.

Los receptadores son los plateros logroñeses Félix Soto, Tomás Eustaquio de Burgos, pero también gente pobre como Agustina Galán, la señora Francisca Blázquez Borja, Antonio San Román, y por el caso adjuntado, Teresa Gómez. Los plateros son ricos, pero Teresa Gómez, madre de José Decía, o los demás no tiene absolutamente nada que embargar. Los plateros pidieron salir de prisión bajo fianza, aludiendo también "a la falta que hace para el manejo de su casa y familia". Mientras que Antonio San Román y Francisca Blázquez Borja, ésta última incluso por mediación de su marido, imploran piedad y "que se le suelte de dicha prisión bajo de caución juratoria, respecto de que por su pobreza no tiene arbitrio para dar fianza alguna".

El corregidor, consciente de la realidad vital de cada uno de los encausados accede a estas peticiones que le hace llegar el procurador Manuel Antonio de Covarrubias, lo cual se plasma también en la sentencia. En ésta condena a pagar a Félix Soto y Tomás Eustaquio de Burgos 3.000 maravedís cada uno, a Agustina Galán 1.000, "los que aplica Su Señoría en la forma ordinaria y en todas las costas desta causa mancomunadamente, y a Francisca Borja Blázquez mediante su Notoria Pobreza, se le apercibe como también a los susodichos que en adelante se abstengan de comprar ninguna Porción de Plata de Persona sospechosa, y menos de Personas de corta hedad, sin dar quenta primero a Su Señoría con apercibimiento que serán castigados con maior rigor. Por lo que mira a Teresa Gómez contra la qual no se ha dicho cosa alguna, mediante su fuga, queda la causa abierta para capturarla y proceder contra ella siempre que pueda ser acusada seguidamente por este su auto así lo proveo y mando y firmo".

A nuestros ojos, sorprende que incluso los receptadores, que como mucho son delincuentes pasivos e inconscientes, ingresen también en prisión, lo que se explica de dos maneras. En primer lugar, por la concepción de la prisión en el Antiguo Régimen, en la que ésta no es una pena, sino la custodia de los sospechosos y un medio más de la investigación, incluso en algunos casos constituye toda una garantía de la Justicia y de la integridad física del encausado frente a las venganzas privadas; y en segundo lugar, porque como bien recuerda el señor corregidor estaba prohibido comprar a menores de edad, y les recrimina el no haber dado rápido aviso a la Justicia tras sospechar que las alhajas habían sido robadas o de procedencia sospechosa. Lógicamente, los receptadores se defienden en su desconocimiento, en su intención de dar aviso a la Justicia pero después de conocer algo más sobre los objetos y los niños tras hablar con los padres etc. En verdad, parece claro que no querían hacer intervenir a la Justicia, pese a sus declaraciones ante ésta claro, pues Félix Soto esperaba hablar con un padre de los chicos, pero en cualquier caso antes de eso ya había efectuado la compra,

59. AHPLR, judicial, caja 76-15, año 1771. 
sin embargo, al enterarse de su procedencia se los devolvió a un eclesiástico de San Blas, Gregorio de Leza, sin dar aviso al corregidor, actuación muy similar a la de Tomás Eustaquio de Burgos. Pese a todo, como hemos podido comprobar, el corregidor ejerce una Justicia paternalista y aleccionadora, menor compresión recibirá con toda seguridad la fugitiva Teresa Gómez, una solución que como afirma el profesor Tomás y Valiente, la fuga, era la única solución para los más desfavorecidos ante una Justicia desigual con los distintos sectores sociales, era el procedimiento más seguro de defensa, con el paso del tiempo el fugado podría pedir un indulto o iniciar una nueva vida echando tierra sobre el proceso. ${ }^{60}$

Las costas se traducen en 129 reales tras la petición de una nueva tasación por parte del procurador. Sanciones pecuniarias muy usuales y extendidas, pues de ellas se nutría la propia Justicia para su mantenimiento. Los muchachos no tuvieron tanta suerte y el corregidor los remite desde la Cárcel Real de Logroño al Arsenal de Burgos. En cuanto a los bienes incautados, las alhajas sustraídas de la iglesia de San Blas y a Ventura Martínez Chacón, vuelven a sus propietarios, mientras que unos relicarios cuya procedencia no ha podido ser averiguada fueron subastados públicamente en la Plaza mayor de la localidad y su importe se destinó a penas de cámara; curiosamente el mejor postor fue el procurador Covarrubias, quién se los quedó por la cantidad 28 reales al no igualarse su postura, cuando ambos relicarios recordemos que estaban tasados en 16.

La dureza con los muchachos se sustenta en que el corregidor los considera vagos y en cumplimiento con las reales ordenanzas les niega la puesta en libertad bajo ningún concepto en todo el proceso: "José Cía, Roque Fernández, Manuel Vicente de Heras, los declara, y declaró, por mal entretenidos, y perjudiciales a la sociedad en concepto de vagos, y comprehendida en la Real Orden que manda se persiga semejante gente, los aplicará, y aplicó Su Señoría, a que sirvan, por cinco años en uno de los Arsenales de Burgos, en los trabajos a que los destinase la persona que corre con el cuidado de semejante gente". ${ }^{61}$

Puede sorprendernos que se dé el mismo trato a los tres muchachos, cuando los dos más jóvenes aparecen como unos mandados "muertos de hambre", esto debe a que en la Justicia del Antiguo Régimen se les considera igualmente culpables, tanto al mandante como a los mandatarios, únicamente podría existir distinción de trato en el caso que en la condición social entre ellos fuera diferente, pero no es éste el caso. O si se les considerara cómplices normalmente la situación sería parecida, aunque el trato pudiera ser diferente a interpretación del juez, que en este caso no existe en base a la acción ejemplarizante que se propone mostrar el corregidor, porque siempre se sentenciaba la pena en proporción de la utilidad social que ésta pudiera tener. ${ }^{62}$

60. TOMÁS Y VALIENTE, El Derecho Penal..., p. 183.

61. AHPLR judicial, caja 76/15, año 1771.

62. Conviene recordar que únicamente los menores de diez años y medio estaban libres de pena; sin embargo, en este caso pesa más el hecho de que se trate de "vagos", un colectivo, 
La pena de los arsenales constituye una variante de la más antigua de galeras, además, las ideas ilustradas que incidían en el bien público convirtieron a estas penas en las más usuales de todo el siglo XVIII, por encima del encierro en los presidios del norte de África y de los trabajos en las minas reales. Esta actuación, más allá de la racionalización y humanización que el pensamiento ilustrado intenta introducir en el derecho penal de la Monarquía, responde en realidad a la falta de mano de obra para los proyectos de renovación naval que se desarrollaban en España a partir del mandato del marqués de la Ensenada en el reinado de Fernando VI (1746-1759), de manera que el preso, sujeto una vez más a las arbitrariedad de las Justicia, se encontraba a merced de las necesidades de la Corona. Así, la influencia de la llustración fue mínima pues las ideas no se plasmaron más allá de lo que le interesó al poder real, tal y como atestigua el hecho de que Carlos III restableciera la pena de galeras en $1784 .{ }^{63}$

En conclusión, y en palabras de M. Foucault, "el cuerpo de los condenados pasaba a ser cosa del rey, sobre el cual el soberano imprimía su marca y dejaba caer los efectos de su poder. Ahora, habrá de ser un bien social, objeto de una apropiación colectiva y útil. Un trabajo público basado en el interés colectivo en la pena del condenado y de carácter visible, controlable, del castigo". Así el culpable paga dos veces, por el trabajo que realiza y por los signos (morales) que produce. Así, los reformistas ilustrados veían en el trabajo público como el mejor de los castigos: "Que los condenados a cualquier pena, menos la de muerte, lo sean a los trabajos públicos del país, por un tiempo proporcionado a su delito". ${ }^{64}$

En definitiva, a la vez que la justicia adoptaba la justificación del utilitarismo se iba desentendiendo de su papel moralizador y así el delincuente no podía redimirse. Veamos un caso ciertamente ejemplar. En 1778, llega a conocimiento del gobernador de la villa de Agoncillo, Manuel Montesinos, que un hombre a caballo acaba de entrar en la localidad y por sospechar que la montura es hurtada, lo manda aprisionar. El sospechoso, Fermín de Roa, venía de pasar cinco años en el presidio de Ceuta, donde había sido condenado por defraudar en la renta del tabaco, es decir, por contrabandista. De hecho, presentó la licencia oficial de libertad ante el gobernador de Agoncillo y el corregidor de Logroño ${ }^{65}$ (que

junto al de gitanos, muy perseguido por la Monarquía, con el agravante de la profanación de sagrado. TOMÁS Y VALIENTE, El Derecho Penal..., pp. 287-294 y p. 340.

63. DE LAS HERAS, J. L., "Los galeotes de la Monarquía Hispánica durante el Antiguo Régimen", Studia histórica. Historia Moderna, Salamanca, Universidad de Salamanca, no 22 (2000), pp. 290-291, 299.

64. Cuaderno de Quejas francés de 1791 citado en FOUCAULT, M., Vigilar y castigar..., p. 113.

65. A cada hombre se le entregaba un pasaporte con su nombre y apellidos acreditando el cumplimiento de su condena, con la única obligación de notificar su nueva residencia. Muchos de ellos, a pesar de recibir advertencias sobre la reincidencia, retomaban su vida delictiva, pues al condenado se le ponía en libertad pero no se le facilitaba medio alguno para regresar a su hogar y generalmente tenía que recurrir a la caridad, o a robar de nuevo. Véase PÉREZ ESTÉVEZ, R. M., El problema de los vagos..., p. 273. 
consta en el archivo). Desde Agoncillo fue conducido a la cárcel de Logroño, donde intenta disminuir su culpa afirmando que "estaba privado del vino" y que tenía intención de devolver el caballo, pues de lo contrario, se habría ido más lejos; simplemente lo tomó para darle recuerdos al señor de Agoncillo de parte de una criada que estaba en Madrid. Ante esta ingenuidad, el corregidor le responde que bien podía haber ido andando y que el señor no vive allí, dictaminando que todo eso no eran más que "excusas frívolas". Poco después, se conoce que en la "taberna de Agoncillo le empezaron a hacer preguntas sobre lo que tenía dispuesto a hacer" y respondió que había tomado el caballo en Logroño "para echar una cuerda para pasar tabaco", es decir, iba a volver a su antiguo oficio tras haber robado el caballo. Según el fiscal, Manuel Antonio de Covarrubias, el reo merece "mayores y más graves penas en que se hayan establecidas por derecho contra semejantes delincuentes. Este acusado reo, en lo mejor de su edad, que debía aplicarse al trabajo, se dedicó al contrabando, por lo que fue destinado a presidio. Y porque cuando debiera haber venido enmendado de contrabandista se metió a ladrón"; además, la excusa del vino es ridícula: "no vale hacer el papel de tonto o borracho". Por eso, la sentencia será contundente: "Debo condenar y condeno al dicho Fermín de Roa a que sirva a Su Majestad por espacio de dos años en uno de sus reales presidios en África, a donde sea conducido por tránsitos, y los que no quebrante pena de cumplirlos doblados, sin costas por ser pobre de solemnidad". El preso salió en junio de 1779 en la "cuerda de presidiarios" rumbo a su destino". ${ }^{66}$

El contrabando era ya por esas fechas un delito especialmente perseguido. Había sido siempre una actividad complementaria al intenso comercio que había en el "cordón del Ebro" entre Navarra, Aragón y Castilla, contando además con la particularidad de las señoríos Vascongados, Provincias Exentas, es decir libres de impuestos. Los pueblos riojanos, como los navarros de la otra parte del río, mantenían el tráfico de tabaco, pimienta, canela, azúcar, cacao, etc. que entraba desde Bayona, mientras los comerciantes bayoneses recibían buena plata española y algunos productos como lana, o aceite. Pero la frontera del Ebro se fue militarizando cada vez más, pues la corona no cesaba de subir los aranceles y de incluir en la lista de productos estancados aquellos que perjudicaban el monopolio indiano. Así, aumentaban los delitos y aunque la mayoría eran juzgados por el gobernador de Cervera del río Alhama -por el célebre Traggia , por ser esa localidad centro principal del contrabando, algunos casos correspondían al corregidor de Logroño, o a los alcaldes de Calahorra y Alfaro. Así, con frecuencia, el corregidor se enfrentaba a delitos de muy poca monta, pero ante los que debía dictar sentencias ejemplares por su severidad. En algunos casos, los reos venían de la autoridad militar encargada de la vigilancia, como en el siguiente, de 1786, referente a un vecino de Aldeanueva de Ebro, contrabandista, cuya casa ha sido registrada por el capitán de infantería y teniente de cazadores del regimiento pro-

66. AHPLR, judicial, caja 2/10, año 1778. 
vincial de Logroño destinado en la ciudad de Calahorra para la persecución de vagos, contrabandistas y malhechores. El jefe militar ha entrado en Aldeanueva "con tropa militar" y ha registrado varias casas, entre ellas la de Venancio Ruiz, en la que halló "dos sacos con sal blanca de contrabando", unas cuatro fanegas. En casa no estaba Venancio, solo su suegra y su mujer. El militar ordenó el embargo de los bienes y que se capture al contrabandista, que obviamente no está en casa, como declara el alcalde de Aldeanueva; la mujer dice que lleva tres meses fuera ganando el jornal. La sal está en el alfolí de Calahorra, custodiada por el teniente de visitador de la renta de salinas del partido de la ciudad de Logroño, que dice que la sal es "sal cuadrada de la prohibida de Navarra". ${ }^{67}$

El Archivo General de Simancas, en la sección Dirección General de Rentas, conserva miles de expedientes sobre estos contrabandistas riojanos, así como informes de las autoridades militares que vigilaban la frontera, que contienen descripciones de lo que, en realidad, era un modo de vida tradicional desde la Edad Media. No es éste el lugar para dar cuenta de todo ello, pero sí para avanzar que esta documentación puede complementar la aportada por M.A. Melón, A. Azcona, R. Torres, etc. ${ }^{68}$ y corroborar que este límite de Castilla con los otros dos reinos de la monarquía configuró un corregimiento bien diferenciado al de otros castellanos, tanto por su condición militar como por sus competencias en la fiscalidad y el contrabando, un delito que a menudo tuvo que juzgar el que invocaba al rey para dictar sentencia, en un tiempo en que mandar era juzgar y las penas y sentencias lecciones de bien obrar para contribuir al mantenimiento del orden social.

\section{Bibliografía}

ALONSO CASTROVIEJO, J. J., "La población de Logroño en los vecindarios de los siglos XVIII y XIX", Brocar: Cuadernos de investigación histórica, n 15 (1989), pp. 45-61.

ALONSO CASTROVIEJO, J. J., Logroño 1751. Según las respuestas generales del Catastro de Ensenada, Madrid, 1990.

ALONSO CASTROVIEJO, J. J., Problemática agraria, solución burguesa, Logroño, 1991.

67. AHPLR, judicial, caja 139, 1, año 1786.

68. Véanse las obras de MELÓN JIMÉNEZ, M. Á., Los tentáculos de la hidra..., Madrid, y AZCONA GUERRA, A. M., Comercio y Comerciantes..., Gobierno de Navarra, 1996; ANGULO MORALES, A., Las puertas de la vida y la muerte: La administración aduanera en las provincias vascas (1690-1780), Bilbao, Servicio Editorial de la Universidad del País Vasco, 1995; GONZÁLEZ ENCISO, A., "El comercio de lanas por la aduana de Ágreda en 1781", Cuadernos de Investigación Histórica, 18 (2001), pp. 319-336; TORRES SÁNCHEZ, R., "El Banco de San Carlos y el negocio del tabaco: una investigación de mercado en el siglo XVIII", en El mercado del tabaco en España durante el siglo XVIII: fiscalidad y consumo, Universidad de Las Palmas de Gran Canaria, 2000, pp. 105-150. 
ANGULO MORALES, A., Las puertas de la vida y la muerte: La administración aduanera en las provincias vascas (1690-1780), Bilbao, Servicio Editorial de la Universidad del País Vasco, 1995.

AZCONA GUERRA, A. M., Comercio y Comerciantes en la Navarra del siglo XVIII, Estella, Gobierno de Navarra, 1996.

BUSTOS TORRE, S., El trabajo y los trabajadores en Logroño entre la peste y la gran crisis castellana (1599-1630), Tesis doctoral, Universidad de La Rioja, 2013.

CASTILLO DE BOVADILLA, Política para corregidores..., edic. fasc. Madrid, 1978.

DELEITO Y PIÑUELA, J., La mala vida en la España de Felipe IV, Madrid, 1987 $\left(1^{\text {a }}\right.$ ed. 1948).

FOUCAULT, M., Vigilar y castigar, Siglo XXI Editores, Madrid, 1975.

FRAILE, P., Un espacio para castigar. La cárcel y la ciencia penitenciaria en España (siglos XVIII-XIX), Madrid, 1987.

GARCÍA VALDÉS, C., Historia de la prisión. Teorías economistas, crítica, Edisofer, Madrid, 1997.

GÓMEZ URDÁÑEZ, J. L., La Hermandad de la Sangre de Cristo de Zaragoza: caridad y ritual religioso en la ejecución de la pena de muerte, reed., Asociación para el Estudio de la Semana Santa, Zaragoza, 2004.

GONZÁlEZ, G., El Guitón Onofre, Edición de Fernando Cabo Aseguinolaza, Logroño, Gobierno de La Rioja, 1995.

GONZÁLEZ ENCISO, A., "El comercio de lanas por la aduana de Ágreda en 1781", Cuadernos de Investigación Histórica, 18 (2001), pp. 319-336.

HERAS, J. L. de las, "Los galeotes de la Monarquía Hispánica durante el Antiguo Régimen", Studia Historica. Historia moderna, 22 (2000), pp. 283-300.

Historia de la ciudad de Logroño, Logroño, 1994, tomos 3 y 4.

IGLESIAS ESTEPA, R., "El recurso a la justicia como vía de resolución de la conflictividad criminal gallega a fines del Antiguo Régimen. El ejemplo de Santiago de Compostela (1700-1834), Studia Historica, 26 (2004), pp. 349-374.

LARDIZÁBAL Y URIBE, M. de, Discurso sobre las penas (1782), Cádiz, Universidad de Cádiz, 2001.

LÁZARO RUIZ, M., La población de la ciudad de Logroño durante el Antiguo Régimen (1500-1833), IER, Logroño, 1994.

LINEBAUGH, P. y REDIKER, M., La hidra de la revolución. Marineros, esclavos y campesinos en la historia oculta del Atlántico, Barcelona, 2005.

LORENZO CADARSO, P. L., La documentación judicial en la época de los Austrias. Estudio archivístico y diplomático, Universidad de Extremadura, Cáceres, 2004. 
LORENZO CADARSO, P. L., Los conflictos populares en Castilla, Madrid, 1997.

LORENZO CADARSO, P. L., "Los malos tratos a las mujeres en Castilla en el siglo XVII", Brocar, 15 (1989), pp. 119-136.

MANTECÓN MOVELLÁN, T., "Desviación, disciplina social e intervenciones judiciales en el Antiguo Régimen", Studia Historica. Historia moderna, 14 (1996), pp. 223-248.

MELÓN JIMÉNEZ, M. Á., Los tentáculos de la hidra. Contrabando y militarización del orden público en España (1784-1800), Madrid, Sílex, 2009.

NAVARRO DOMíNGUEZ, J. M., "Delincuencia en Carmona a fines del siglo XVIII a través de las fianzas de cárcel", Ascil. Anuario de Estudios Locales, año 5, 4 (2010), pp. 12-15.

NIEVES GÁLVEZ, I., "La justicia y las conductas delictivas en Niebla y su tierra (1700-1750), Huelva en su historia-Segunda época, 8 (2001), pp. 187-201.

ORTEGA LÓPEZ, M., "Violencia familiar en el pueblo de Madrid durante el siglo XVIII", Cuadernos de Historia Moderna, 31 (2006), Universidad Autónoma de Madrid, Madrid, pp. 7-37.

PEÑA MATEOS, J., "Antecedentes de la prisión como pena privativa de libertad en Europa hasta el siglo XVII", GARCÍA VALDÉS, C., Historia de la prisión. Teorías economistas, crítica, Edisofer, Madrid, 1997, pp. 63-78.

PÉREZ ESTÉVEZ, M. R., El problema de los vagos en la España del siglo XVIII, Madrid, Confederación Española de Cajas de Ahorros, 1976.

PÉREZ SARRIÓN, G., El Canal Imperial y la navegación hasta 1812, Zaragoza, 1975.

RHEINHEIMER, M., Pobres, mendigos y vagabundos, Madrid, 2009.

SOUBEYROUX, J., "El encuentro del pobre y la sociedad: asistencia y represión en el Madrid del siglo XVIII", Estudios de historia social, 20-21 (1982), pp. $7-225$.

SOUBEYROUX, J. y FERNÁNDEZ, R. (coords.), Familia y clases populares en España (siglos XVIII-XIX), Lleida, 2001.

TOMÁS Y VALIENTE, F., El Derecho penal de la monarquía absoluta (siglos XVI, XVII y XVIII), Tecnos, Madrid, 1969 (1992).

TORRES SÁNCHEZ, R., "El Banco de San Carlos y el negocio del tabaco: una investigación de mercado en el siglo XVIII", en SOLBES FERRI, S., LAFORET HERNÁNDEZ, J. J. y DELUXAN MELÉNDEZ, S. (coords.), El mercado del tabaco en España durante el siglo XVIII: fiscalidad y consumo, Universidad de Las Palmas de Gran Canaria, 2000, pp. 105-150. 